\title{
Food insecurity and nutritional status of preconception women in a rural population of North Karnataka, India
}

\author{
Shivanand C. Mastiholi', Manjunath S. Somannavar ${ }^{1 *}$, Sunil S. Vernekar ${ }^{1}$, S. Yogesh Kumar ${ }^{1}$, Sangappa M. Dhaded ${ }^{1}$, \\ Veena R. Herekar ${ }^{1}$, Rebecca L. Lander ${ }^{2}$, Michael K. Hambidge², Nancy F. Krebs ${ }^{2}$ and Shivaprasad S. Goudar ${ }^{1}$
}

From 2nd International Conference on Maternal and Newborn Health: Translating Research Evidence to Practice

Belagavi, India. 26-27 March 2018

\begin{abstract}
Background: As per the World Health Organization, the nutritional status of women of reproductive age is important, as effects of undernutrition are propagated to future generations. More than one-third of Indian women in the reproductive age group are in a state of chronic nutritional deficiency during the preconception period leading to poor health and likely resulting in low birth weight babies. This study was aimed to assess the food insecurity and nutritional status of preconception women in a rural population of north Karnataka.

Methods: A total of 770 preconception women were enrolled across a district in Karnataka from selected primary health centre areas by a cluster sampling method. Data on socioeconomic status, food insecurity and obstetric history were collected by trained research assistants, interviewing women at home. In half of the participants, a 1 day 24 -hour dietary recalls were conducted by dietary assistants to assess the dietary intakes. Anthropometric measurements and haemoglobin estimation were carried out at the health centres.

Results: In the present study, a majority of the participants (64.8\%) belonged to the lower socio-economic classes and the prevalence of food insecurity was $27.4 \%$. A majority of the participants had mild (15.5\%) to moderate (78.6\%) anaemia. About one-third of the participants (36.6\%) were underweight. Significant associations were found between socio-economic status and anaemia $(p=0.0006)$ and between food insecurity and anaemia $(p=0.0001)$.
\end{abstract}

Conclusion: The nutritional status of preconception women was poor and anemia was more prevalent in low-socioeconomic and food insecure population.

Keywords: Preconception women, Nutritional status, Socio-economic status and food insecurity

\section{Background}

Malnutrition, especially undernutrition is prevalent in developing countries and the adverse effects of poor nutrition on pregnancy outcomes have been well documented. [1] Reproductive-aged women are at risk of iron deficiency because of blood loss from menstruation, poor diet, and frequent pregnancies [2]. Resource poor settings like in India affect the health and nutritional

\footnotetext{
* Correspondence: manjunathsomannavar@gmail.com

${ }^{1}$ Women's and Children's Health Research Unit, KLE Academy of Higher Education and Research's Jawaharlal Nehru Medical College, Belagavi, Karnataka, India

Full list of author information is available at the end of the article
}

status of women of reproductive age exacerbated by prevailing cultural and traditional practices. [3, 4] Women are at high risk of inadequate micronutrient intakes as their diets are of low-quality, lack diversity and are dominated by staple foods. [5] In India, like other low resource settings, women are vulnerable to undernutrition for social and biological reasons throughout their lifecycle. $[6,7]$

Maternal nutritional status is important for the health and quality of life of women and for the health of their newborns. India is home to more than 217 million undernourished people as per The State of Food 
Insecurity in the World (2012) estimates [8]. Previous studies in Indian urban settings have found the prevalence of food insecurity ranging from 51 to $77 \%$ [9-12]. However, data on food insecurity in the rural areas is lacking which constitutes about $70 \%$ of Indian population. [13] This study was aimed to assess the food insecurity, socio demographic factors, nutritional status, macro and micronutrient adequacy of diets in the preconception period among rural women of North Karnataka.

\section{Methods}

This was a cross sectional study conducted from January to December 2014. A total of 770 preconception women were enrolled belonging to 18 villages from five counties across the Belagavi district in Karnataka state. Women were identified through a household survey and selected by a cluster sampling method with the help of Nurse Midwives and Accredited Social Health Activists (ASHAs). Non-pregnant and non-lactating women with parity $0-3$ were included. Those with haemoglobin less than $8 \mathrm{~g} / \mathrm{dL}$ and/or who were using permanent and temporary methods of birth control were excluded. The study was approved by J N Medical College, Belagavi Institutional Ethics Committee on Human Subjects Research. Informed written consent was obtained from each study participant.

Socio-demographic, obstetric and food insecurity data were collected by trained Home Visit Research Assistants (HVRA) by interviewing women in their households. Information regarding per capita income (in Rupees/month) was collected and socio-economic status (SES) was classified using the Modified Prasad classification for the study period (2014). SES was classified as upper, upper middle, middle, lower middle and lower Class based on per capita monthly income of Rupees 5357 and above, 2652-5356, 1570-2651, 812-1569 and 811 or less respectively [14] Information regarding parity, age of marriage and history of consanguinity (matrimony between closely related individuals) were collected as part of obstetric history. Food insecurity status was assessed based on a nine item questionnaire and categorized into four types: food secure, mildly food insecure, moderately food insecure and severe food insecure using Household Food Insecurity Access Scale (HFIAS) for measurement of food access [15].

Hemoglobin (Sahli's Method) [16] was estimated by trained technicians using capillary blood in the health centres and anaemia was graded as per WHO criteria [17]. The anthropometric measurements were carried out in primary health centres. Maternal height, weight, mid-upper arm circumference (MUAC), waist, and hip circumference measurements were obtained by a specially trained assessment team utilizing standardized
Table 1 Socio-demographic parameters, Food Security and Anaemic status of preconception women

\begin{tabular}{|c|c|c|c|}
\hline Variables & & $\mathrm{N}$ & Percentage \\
\hline \multirow[t]{5}{*}{ Age: } & $15-19$ years & 126 & 16.4 \\
\hline & 20-24 years & 436 & 56.6 \\
\hline & $25-29$ years & 174 & 22.6 \\
\hline & $30-34$ years & 28 & 3.6 \\
\hline & $35-39$ years & 6 & 0.8 \\
\hline \multirow[t]{3}{*}{ Religion: } & Hindu & 649 & 84.3 \\
\hline & Muslim & 119 & 15.5 \\
\hline & Others & 2 & 0.3 \\
\hline \multirow[t]{5}{*}{ Education: } & Illiterate & 52 & 6.8 \\
\hline & Primary & 228 & 29.5 \\
\hline & Secondary & 331 & 43.0 \\
\hline & PUC & 123 & 16.0 \\
\hline & $\begin{array}{l}\text { Graduate/Post } \\
\text { graduate }\end{array}$ & 36 & 4.7 \\
\hline \multirow[t]{5}{*}{ Socio economic status: } & Upper class & 6 & 0.8 \\
\hline & Upper Middle class & 22 & 2.9 \\
\hline & Middle class & 58 & 7.5 \\
\hline & Lower Middle class & 185 & 24.0 \\
\hline & Lower class & 499 & 64.8 \\
\hline Lacto-Vegetarian Diet: & & 375 & 48.7 \\
\hline Age of marriage: $<18$ & & 291 & 37.8 \\
\hline Consanguinity (Yes) & & 290 & 37.7 \\
\hline \multirow[t]{4}{*}{ Parity: } & Nulliparous & 258 & 33.5 \\
\hline & 1 child & 338 & 43.9 \\
\hline & 2 child & 141 & 18.3 \\
\hline & $3+$ child & 33 & 4.3 \\
\hline \multirow[t]{3}{*}{ Hemoglobin: G/dL } & $\begin{array}{l}\text { Moderate Anemia } \\
(8-10.9)\end{array}$ & 605 & $78.6 \%$ \\
\hline & $\begin{array}{l}\text { Mild Anemia (11- } \\
11.9)\end{array}$ & 119 & $15.5 \%$ \\
\hline & Normal ( $\geq 12)$ & 46 & $5.9 \%$ \\
\hline \multirow[t]{4}{*}{$\begin{array}{l}\text { Household food insecurity } \\
\text { access (HFIA) category }\end{array}$} & $\begin{array}{l}\text { Food secure (HFAl } \\
\text { 1) }\end{array}$ & 559 & 72.6 \\
\hline & $\begin{array}{l}\text { Mild food insecure } \\
\text { (HFAl 2) }\end{array}$ & 84 & 10.9 \\
\hline & $\begin{array}{l}\text { Moderate food } \\
\text { insecure (HFAl 3) }\end{array}$ & 92 & 11.9 \\
\hline & $\begin{array}{l}\text { Severe food } \\
\text { insecure (HFAl 4) }\end{array}$ & 35 & 04.6 \\
\hline
\end{tabular}

calibrated study equipment. Subjects were lightly clothed with no footwear. Height was recorded to the nearest $0.1 \mathrm{~cm}$ and weight to the nearest $0.1 \mathrm{~kg}$ by utilizing stadiometer and electronic weighing scales respectively. MUAC and, Waist and Hip Circumferences were recorded to the nearest $0.1 \mathrm{~cm}$ by Circumference insertion measuring tape and retractable tapes respectively. BMI 
$\left(\mathrm{kg} / \mathrm{m}^{2}\right)$ was calculated from recorded height and weight. The WHO recommended appropriate Body Mass Index (BMI) for Asian populations and their cut-off values were used for classification. Women were classified as underweight, Normal, Overweight and Obese based on BMI of less than $18.5,18.5$ to $22.9,23$ to 24.9 and more than or equal to 25 respectively. [18-20]

One day 24-h dietary recall was conducted by the trained dietary assistants in half of the study participants to estimate the intake of macro and micronutrients. Additionally, in $30 \%$ of the study participants, repeat dietary recall was performed to validate the nutritional intakes (Data not shown). The method employed for the 24-h dietary recall is published elsewhere [21].

Socio-demographic and food insecurity variables were presented as descriptive statistics. Nutrient intakes and anthropometric parameters were summarized as means and standard deviations. Chi-square tests were used to define the association between various sociodemographic variables and food insecurity, Anemia and poor nutrient intake (proportion of women with less than $50 \%$ intake of recommended daily allowance) with a significance level of 0.05. Data was entered in excel to prepare a master chart. SPSS version 21.0 software was used for analysis of the data.

\section{Results}

A total of 770 participants were included in the study. The mean age of the participants was 22.5 (SD $\pm 3.19)$ years and the majority $(93.6 \%)$ were less than 30 years. The majority of participants $(84.3 \%)$ were Hindus whereas Muslims constituted 15.5\%. Almost two-third of the participants $(65 \%)$ had studied at a secondary or higher level. The majority of the women (89\%) were classified as low or lower middle socioeconomic class. About 38\% of the participants had a history of consanguineous marriage and slightly more than one third were married before the age of 18 years (37.8\%). Forty-four percent of the preconception women had one child and $33.5 \%$ were nulliparas. Almost $94 \%$ of the women were anaemic with $78.6 \%$ and $15.5 \%$ classified as moderate and mild anemia respectively. Nearly a quarter of households were mild to moderate food insecure (27.4\%) with severe food insecurity among 4.6\% (Table 1) Food insecurity was prevalent across all the SES categories. It was found to be $33.7 \%$ in upper, upper-middle and middle classes, $28.1 \%$ in lower middle classes and $26.1 \%$ in lower class families but the differences were not statistically significant ( $p=0.4334)$. (Fig. 1).

One third of the study participants (36.6\%) were underweight and about 18\% were either overweight $(8.7 \%)$ or obese $(9.1 \%)$. The mean MUAC of the participants was $24.1 \mathrm{~cm}$. Nearly $25 \%$ of the participants had a MUAC less than $22.0 \mathrm{~cm}$. A total of $180(23.4 \%)$ participants had $\mathrm{W} / \mathrm{H}$ ratio more than or equal to 0.8 (Table 2).

The mean and median intakes of energy, macro and micronutrients are presented in Table 3 . With respect to the energy and macronutrients, the proportion of women consuming less than $50 \%$ of the RDA were 15 . $8 \%$ for energy, $39.6 \%$ for protein and $18.2 \%$ for lipids. The consumption deficit was even greater for micronutrients. The proportion of women taking less than half of the required daily allowance for calcium, iron, zinc, vitamin $\mathrm{B} 12$, folate, vitamin $\mathrm{C}$ and vitamin $\mathrm{A}$ was $32.8 \%$, $77.7,54.5,35.4,43.9,38.5$ and $44.5 \%$ respectively.

The anaemia prevalence was $94.1 \%$ and found to be present in women across all the SES categories. About $70 \%$ of the women from upper, upper-middle and middle income families had moderate anaemia whereas prevalence was more in lower-middle (73\%) and lower

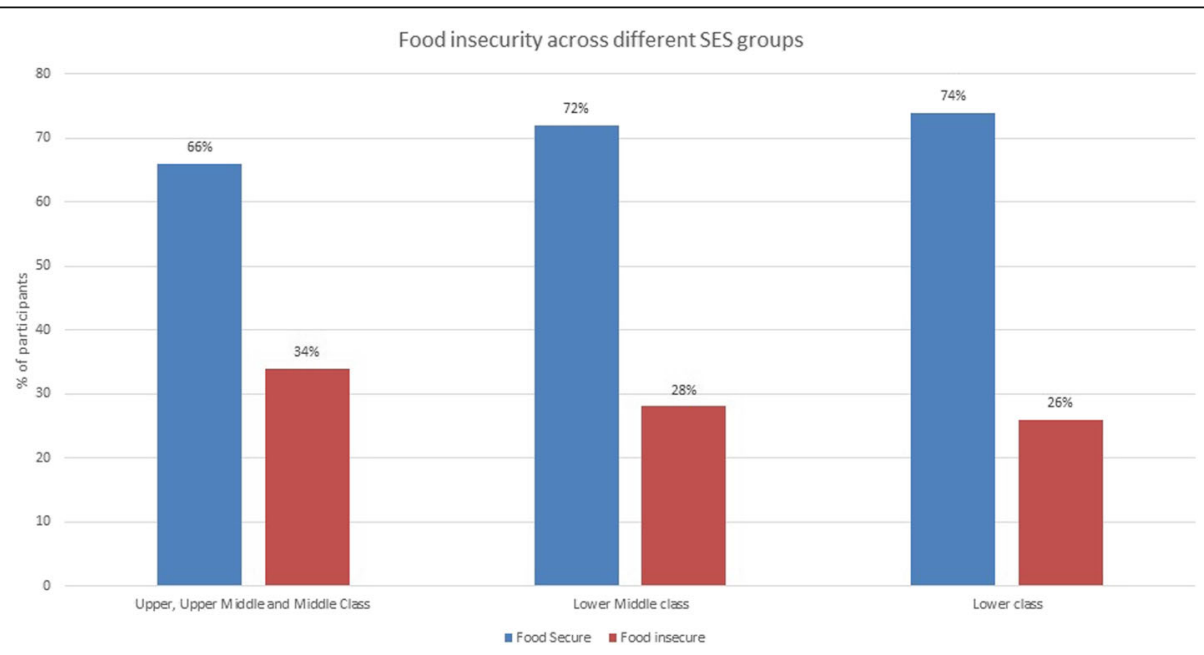

Fig. 1 Prevalence of Food insecurity among different Socioeconomic classes 
Table 2 Anthropometric parameters

\begin{tabular}{|c|c|c|}
\hline Variables & $\mathrm{N}(\%)(n=770)$ & Mean \pm SD \\
\hline Height (in cm) & & $151.42 \pm 5.58$ \\
\hline Weight (in kg) & & $46.212 \pm 8.4398$ \\
\hline BMI: $\left(\mathrm{Kg} / \mathrm{m}^{2}\right)$ & & $20.09 \pm 3.39$ \\
\hline Underweight (< 18.5) & $282(36.6 \%)$ & \\
\hline Normal (18.5-22.9) & $351(45.6 \%)$ & \\
\hline Overweight (23-24.9) & $67(8.7 \%)$ & \\
\hline Obese $\geq 25$ & 70 (9.1\%) & \\
\hline Waist circumference (cm) & & $65.18 \pm 8.44$ \\
\hline Hip circumference $(\mathrm{cm})$ & & $85.22 \pm 7.14$ \\
\hline W/H ratio & & $0.76 \pm 0.06$ \\
\hline$<0.8$ & 590 (76.6\%) & \\
\hline$\geq 0.8$ & 180 (23.4\%) & \\
\hline MUAC (cm) & & $24.06 \pm 3.06$ \\
\hline$<22$ & 189 (24.5\%) & \\
\hline$\geq 22$ & $581(75.5 \%)$ & \\
\hline
\end{tabular}

(82.2\%) income families. Mild anemia was observed in $27.9 \%$ of upper, upper-middle and middle compared to 18.9 and $12 \%$ in lower-middle and lower income families respectively. The severity of anaemia was greater in lower SES categories and the association was statistically significant $(p=0.0006)$. (Table 4$)$. Anaemia was more common in food secure (95.8\%) than in food insecure (89.1\%) women. Prevalence of moderate anemia was higher $(82.6 \%)$ in food secure than in food insecure $(67.8 \%)$ women. However, mild anemia was more prevalent in food insecure $(21.3 \%$ vs $13.2 \%)$ women and the results
Table 4 Prevalence of anemia among different Socioeconomic classes

\begin{tabular}{|c|c|c|c|c|}
\hline \multirow[t]{2}{*}{ Socio economic status (SES) } & \multicolumn{3}{|c|}{ Anaemia status } & \multirow[t]{2}{*}{ Total } \\
\hline & $\begin{array}{l}\text { Moderate } \\
\text { Anaemia }\end{array}$ & $\begin{array}{l}\text { Mild } \\
\text { Anaemia }\end{array}$ & Normal & \\
\hline $\begin{array}{l}\text { Upper, Upper Middle and } \\
\text { Middle Class }\end{array}$ & $60(69.8 \%)$ & $24(27.9 \%)$ & $\begin{array}{l}2 \\
(2.3 \%)\end{array}$ & 86 \\
\hline Lower Middle class & $135(73.0 \%)$ & $35(18.9 \%)$ & $\begin{array}{l}15 \\
(8.1 \%)\end{array}$ & 185 \\
\hline Lower class & $410(82.2 \%)$ & $60(12 \%)$ & $\begin{array}{l}29 \\
(5.8 \%)\end{array}$ & 499 \\
\hline Total & 605 & 119 & 46 & 770 \\
\hline \multicolumn{4}{|l|}{$X^{2}=19.6201 D F=4 p=0.0006$} & \\
\hline
\end{tabular}

were statistically significant. $(p=0.00001)$ (Fig. 2$)$. The prevalence of moderate anaemia was slightly lower in Lacto-vegetarians $(75.2 \%)$ than non-vegetarians $(81.1 \%)$, whereas mild anemia was more prevalent in Lactovegetarians $(18.5 \%$ vs $12.7 \%)$, which was not statistically significant $(\mathrm{p}=0.067771)$. (Table 5 ) The association between dietary intake of micronutrients (iron, vitamin B6, folate and vitamin B12) and anaemia in vegetarians and non-vegetarians is presented in Table 6. There were no statistical differences in intake of these micronutrients and anaemia status in both the vegetarian and nonvegetarian groups.

\section{Discussion}

The results of the study indicate that nutritional status of preconception women is suboptimal although food insecurity does not appear to be a major concern in this population. Almost all of the women

Table 3 Calorie and nutrient intake on selected Macro and micronutrients $(n=392)$

\begin{tabular}{|c|c|c|c|}
\hline Nutrient (RDA) & Mean \pm SD & Median & $\begin{array}{l}\text { Proportion of women with intake } \\
<50 \% \text { of RDA }\end{array}$ \\
\hline Calorie (Kcal) (1900 kcal) & $1302.66 \pm 358.50$ & 1263.32 & 15.8 \\
\hline Protein (g) (55 g) & $31.24 \pm 11.07$ & 29.77 & 39.6 \\
\hline $\mathrm{CHO}(\mathrm{g})(280 \mathrm{~g})$ & $183.64 \pm 49.42$ & 180.67 & 1.0 \\
\hline Total lipids (Fat)(g) (40 g) & $50.47 \pm 17.78$ & 48.72 & 18.2 \\
\hline Fiber (g) (30 g) & $15.57 \pm 5.25$ & 14.97 & 49.8 \\
\hline Calcium(mg) (600 mg) & $453.68 \pm 252.16$ & 389.59 & 32.8 \\
\hline Iron(mg) (21 mg) & $8.20 \pm 3.04$ & 7.82 & 77.7 \\
\hline Zinc(mg) (10 mg) & $5.04 \pm 1.76$ & 4.79 & 54.5 \\
\hline Vit B1(Thiamine)(mg) (1 mg) & $0.51 \pm 0.18$ & 0.50 & 49.0 \\
\hline Vit B2 (Riboflavin)(mg) (1.1 mg) & $0.75 \pm 0.29$ & 0.72 & 24.2 \\
\hline Vit B6 (Pyridoxal phosphate PLP)(mg) (2 mg) & $0.97 \pm 0.34$ & 0.95 & 57.6 \\
\hline Dietary folate equiv.(DFE)( $\mu g)(200 \mu g)$ & $125.16 \pm 67.03$ & 112.35 & 43.9 \\
\hline Vit B12 (Cobalamin)( $\mu \mathrm{g})(1 \mu \mathrm{g})$ & $0.92 \pm 0.80$ & 0.621 & 35.4 \\
\hline Vit C (Ascorbic acid)(mg) (40 mg) & $30.33 \pm 22.54$ & 24.69 & 38.5 \\
\hline Vit A RAE $(\mu \mathrm{g})(400 \mu \mathrm{g})$ & $266.54 \pm 178.26$ & 216.28 & 44.5 \\
\hline
\end{tabular}


Food insecurity Vs Anaemia

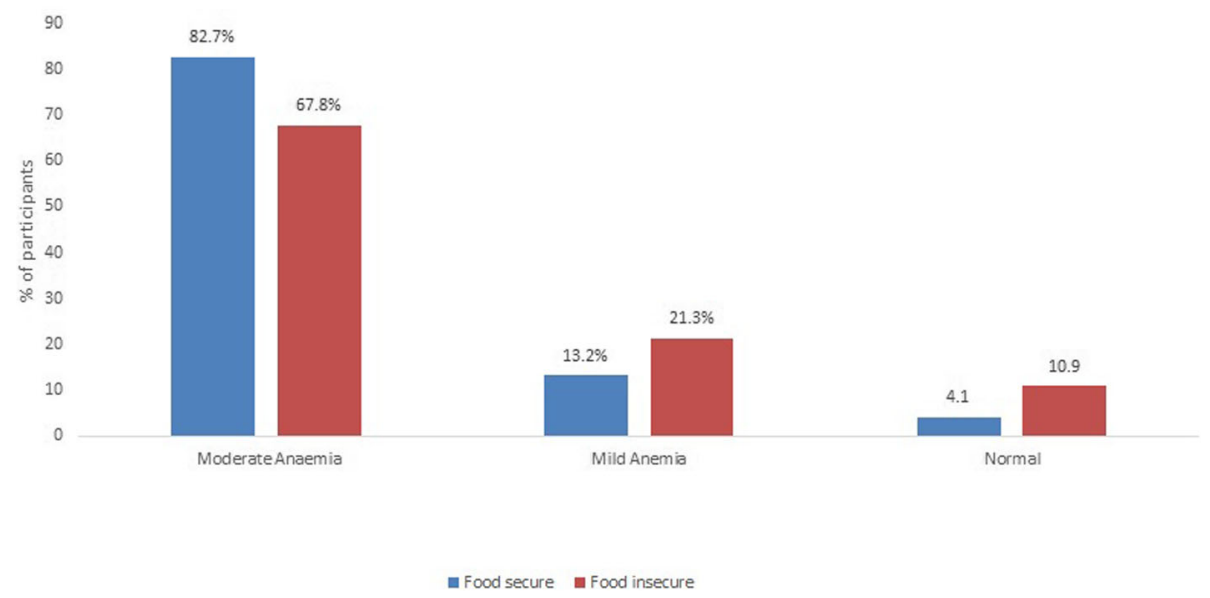

Fig. 2 Prevalence of Anemia among food secure and insecure women

were anemic, about one-third underweight, majority had inadequate intake of micro and macronutrients and one-fourth were food insecure.

This was a community based study with participants identified through household survey of Married Women of Reproductive Age from a cross section of rural areas of Belagavi District of North Karnataka region of India. Food insecurity as well as socioeconomic and nutritional status were determined using validated assessment methods. Additionally, actual intake of macro and micronutrients was assessed by a 24-h dietary recall by a trained dietician. Though less accurate, Haemoglobin level of the participants was estimated by Sahli's method since the Primary Health Centres generally use this method and is recommended for community screening of anemia. [22, 23] Further, type of anemia was not evaluated in this study. Additionally, clustering was not accounted for in the analysis.

Studies conducted in central and eastern India have reported the prevalence of mild to moderate anaemia in the range of 42.1 to $60.8 \%$ and 39.6 to $48.0 \%$ respectively. [24, 25] However, National Family Health Survey2015-16 (NFHS-4) reported a lower prevalence of anaemia (41.2\% for Belagavi district and $46.1 \%$ for Karnataka state). [26, 27] The lower prevalence may be due to methodological differences in the estimation of Hemoglobin. We found that anaemia was prevalent

Table 5 Association between type of diet and anemia

\begin{tabular}{lllll}
\hline & Moderate Anemia & Mild Anemia & Normal & Total \\
\hline Lacto-vegetarians & $282(75.2 \%)$ & $69(18.5 \%)$ & $24(6.3 \%)$ & 375 \\
Non-vegetarians & $323(81.1 \%)$ & $50(12.7 \%)$ & $22(6.2 \%)$ & 395 \\
Total & 605 & 119 & 46 & 770 \\
\hline
\end{tabular}

among all the women irrespective of their socioeconomic strata, however, the severity of anaemia was greater among lower SES women. Anthropometric evaluation showed that most of the women had either a normal BMI or were underweight. A study done in a South Indian state [28] showed that $31.3 \%$ of preconception women were undernourished and NFHS-4 reported a comparatively lower prevalence $(20.6 \%$ for Belagavi District and 24.3\% for Karnataka state) [26, 27]. Another study in neighbouring Bangladesh [29] showed that $25.6 \%$ of preconception women, especially adolescents were undernourished.

Evaluation of the recommended daily allowance and the actual intake of various macro and micronutrients showed that the diet was rich in carbohydrates and fats. The food consumption pattern in this population showed that the caloric intake was relatively adequate in majority of the women. However, the total protein, fibre and essential micronutrient intake was low in the study participants. Earlier studies have reported poor nutritional status in women of reproductive age. [5, 30-34] In the present study, nearly half the participants were Lacto-vegetarians and the type of diet was not associated with prevalence of anaemia. Additionally, intake of important hematopoietic micronutrients such as Iron, Vitamin B6, Folate and Vitamin B12 was not associated with prevalence of anaemia in both the vegetarian and non-vegetarian population. Hence, it may be inferred that vegetarianism may not be a major contributing factor to cause anaemia.

Food insecurity was not a major concern in the study group which was found only in $27.4 \%$ families compared to reported prevalence among urban and tribal communities of India. [9-12] Similar findings 
Table 6 Association between dietary intake of micronutrients and anemia in vegetarians and Non-vegetarians

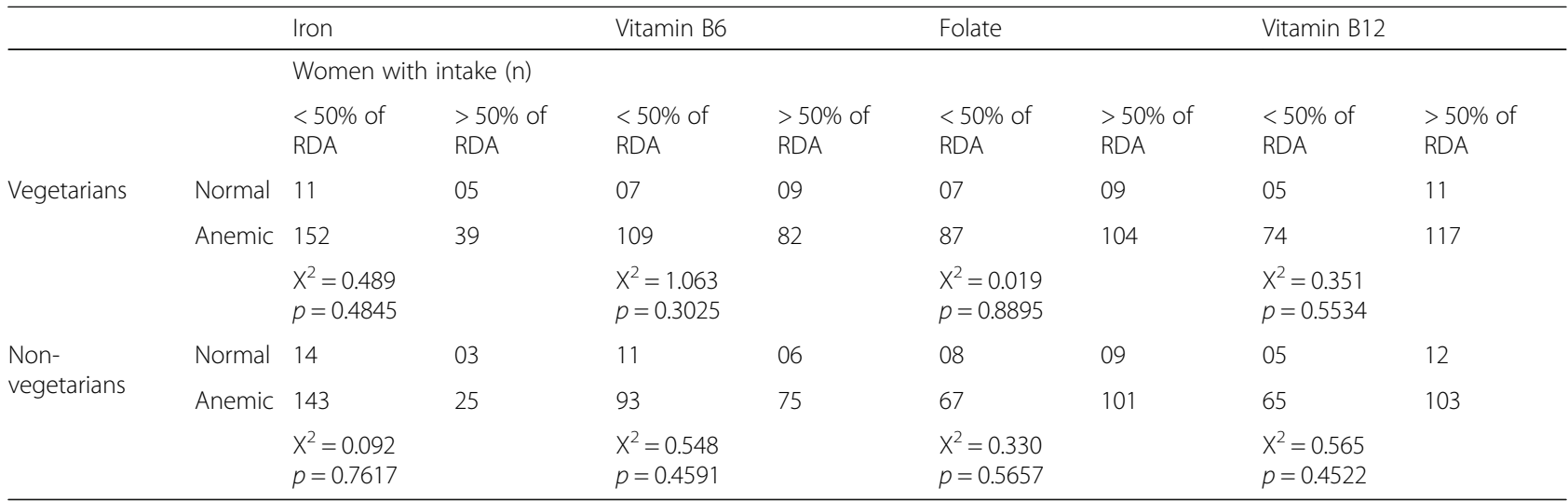

were observed in a study conducted in north India where $25 \%$ of the households were food insecure. [35] A study conducted in the Western Highlands of Guatemala [36] revealed that, $35.9 \%$ of women were food secure, $46.1 \%$ had moderate food insecurity and $18 \%$ women had severe food insecurity. Regardless of the reported food security status, more than threefourth of women in both food secure and insecure groups were anaemic. It was observed that food security was not a protective factor to prevent women from being anaemic. This can be attributed to the dietary and cultural norms in the society wherein most of the population is vegetarian and where the diet is protein deficit. Another issue is that the society is male dominated where females eat the left over, less nutritious food. We can safely infer that food security does not ensure food quality. Higher food security among low socio-economic strata families compared to lower middle and upper classes can be attributed to various schemes of government like provision of food grains (Rice, Wheat and Finger Millet), sugar and palm oils free of cost or at a highly subsidized rate for low socioeconomic people in the society. [37] Preconception care can make a useful contribution to reducing maternal and childhood morbidity and mortality and also improve maternal and child health in both high- and low-income countries. [38] Results of this study are important as the nutritional status of the preconception women in this population is poor and might impact the health of both mother and child.

\section{Conclusion}

The nutritional status of preconception women is poor and food security is common in this population. Anaemia in women of reproductive age group can be a major public health hazard if not addressed strongly. The health of a woman in the reproductive age group has direct implications on the health of the new born babies she will bear in the future. Though emphasis is given for nutrition during pregnancy, there is an urgent need to create awareness and implement interventions to improve the nutritional status during the preconception period itself so as to improve the maternal health and in turn child health.

\section{Abbreviations}

ASHA: Accredited social health activist; BMI: Body mass index;

HFIAS: Household food insecurity access scale; HVRA: Home visit research assistant; MUAC: Mid upper arm circumference

\section{Acknowledgements}

Some of the data presented (Anthropometry and Food insecurity) here was collected as part of Women First: Preconception Maternal Nutrition Trial. We sincerely wish to thank all the participants in the study.

\section{Funding}

The study was funded by the Indian Council of Medical Research (ICMR), New Delhi. Publication charges for this supplement were funded by the University of British Columbia PRE-EMPT (Pre-eclampsia/Eclampsia, Monitoring, Prevention and Treatment) initiative supported by the Bill \& Melinda Gates Foundation.

\section{Availability of data and materials}

The datasets used and/or analysed during the current study are available from the corresponding author on reasonable request.

\section{About this supplement}

This article has been published as part of Reproductive Health Volume 15 Supplement 1, 2018: Improving pregnancy outcomes - Proceedings of the 2nd International Conference on Maternal and Newborn Health: Translating Research Evidence to Practice. The full contents of the supplement will be available online at https://reproductive-health-journal.biomedcentral.com/ articles/supplements/volume-15-supplement-1.

\section{Authors' contributions}

SCM conceived of the manuscript and wrote the first draft with input from MSS, SSV, YS, RL, NFK, MKH and SSG. SCM, MSS, SSV, VRH, YS and SSG oversaw study implementation, data collection and quality monitoring. SCM, MSS, YS and SSV performed the statistical analyses. All authors reviewed and approved the final manuscript.

\section{Ethics approval and consent to participate}

This study was reviewed and approved by ethics review committee at KLE University's Jawaharlal Nehru Medical College, Belagavi. All women provided informed consent for participation in the study.

Competing interests

The authors declare that they have no competing interests. 


\section{Publisher's Note}

Springer Nature remains neutral with regard to jurisdictional claims in published maps and institutional affiliations.

\section{Author details}

'Women's and Children's Health Research Unit, KLE Academy of Higher Education and Research's Jawaharlal Nehru Medical College, Belagavi, Karnataka, India. ${ }^{2}$ Department of Pediatrics, Section of Nutrition, University of Colorado School of Medicine, Aurora, CO, USA.

\section{Published: 22 June 2018}

\section{References}

1. Blössner M, De Onis M, Prüss-Üstün A. Malnutrition: quantifying the health impact at national and local levels / Monika Blössner and Mercedes de Onis. Geneva: World Health Organization; 2005. http://www.who.int/iris/handle/ $10665 / 43120$

2. Kassa GM, Muche AA, Berhe AK, Fekadu GA. Prevalence and determinants of anemia among pregnant women in Ethiopia; a systematic review and meta-analysis. BMC Hematol. 2017 Oct 17;17:17.

3. American College of Obstetricians and Gynecologists. ACOG practice bulletin no. 95: Anemia in pregnancy. Obstet Gynecol. 2008;112:201-7.

4. Mallikarjun RK, Balakrishanan N, Aralappa N, Laxmaiah A, Brahmam NV. Diet and nutrition status of women in India. J Hum Ecol. 2010;29(3):165-70,

5. Torheim LE, Ferguson EL, Penrose K, Arimond M. Women in resource-poor settings are at risk of inadequate intakes of multiple micronutrients. J Nutr. 2010 Nov;140(11):205 1S-8S.

6. Black RE, Allen LH, Bhutta ZA, Caulfield LE, de Onis M, Ezzati M, et al. Maternal and child undernutrition: global and regional exposures and health consequences. Lancet. 2008 Jan 19;371(9608):243-60.

7. Hanson MA, Bardsley A, De-Regil LM, Moore SE, Oken E, Poston L, et al. The International Federation of Gynecology and Obstetrics (FIGO) recommendations on adolescent, preconception, and maternal nutrition: "think nutrition first". Int J Gynaecol Obstet. 2015 Oct;131(Suppl 4):S213-53.

8. FAO/WFP/IFAD. The State of food insecurity in the world 2012: economic growth is necessary but not sufficient to accelerate reduction of hunger and malnutrition. Rome: Food and Agriculture Organization, 2012. 61 p.

9. Chinnakali P, Upadhyay RP, Shokeen D, Singh K, Kaur M, Singh AK, et al. Prevalence of household-level food insecurity and its determinants in an urban resettlement colony in North India. J Health Popul Nutr. 2014 Jun; 32(2):227-36.

10. Gopichandran V, Claudius P, Baby LS, Felinda A, Mohan VR. Household food security in urban Tamil Nadu: a survey in Vellore. Natl Med J India. 2010;23: 278-80.

11. Mukhopadhyay DK, Mukhopadhyay S, Biswas AB. Enduring starvation in silent population: a study on prevalence and factors contributing to household food security in the tribal population in Bankura, West Bengal. Indian J Public Health. 2010:54:92-7.

12. Agarwal S, Sethi V, Gupta P, Jha M, Agnihotri A, Nord M. Experiential household food security in an urban underserved slum of North India. Food Sec. 2009;1:239-50.

13. Urban and Rural Population of India 2011 - Indiafacts.in available at http:/ indiafacts.in/india-census-2011/urban-rural-population-o-india/00

14. Mangal A, Kumar V, Panesar S, Talwar R, Raut D, Singh S. Updated BG Prasad socioeconomic classification, 2014: a commentary. Indian J Public Health. 2015:59:42-4.

15. Coates, Jennifer, Anne $S$ and Paula B: Household Food Insecurity Access Scale (HFIAS) for Measurement of household food access: Indicator guide (v.3). Washington D.C.: FANTA, Academy for educational development. 2007; 3: 5-21.

16. Pal GK, Pal Parvati. Text book of Practical Physiology. 2nd Ed., Orient Longman, Chennai, India; 2005:13-14.

17. WHO. Haemoglobin concentrations for the diagnosis of anemia and assessment of severity. Nutrition and Health Department, World Health Organization;2011:3. Available at http://apps.who.int/iris/bitstream/10665/ 85839/3/WHO_NMH_NHD_MNM_11.1_eng.pdf?ua=1

18. Hambidge KM, Krebs NF, Garcés A, Westcott JE, Fiqueroa L, Goudar SS, et al. Anthropometric indices for non-pregnant women of childbearing age differ widely among four low-middle income populations. BMC Public Health. 2017 Jul 24;18(1):45.
19. World Health Organization, Physical Status: The use and interpretation of Anthropometry. Technical Report Series No. 854. Geneva; 1995: 3-7.

20. The World Health Organization Western Pacific Region (WHO-WPR), the International Association for the Study of Obesity (IASO) and the International Obesity Task Force (IOTF). The Asia-Pacific perspective: Redefining obesity and its treatment. Health Communications Australia Pty Ltd.2000:1-55.

21. Lander RL, Hambidge KM, Krebs NF, Westcott JE, Garces A, Figueroa L, et al. Repeat 24-hour recalls and locally developed food composition databases: a feasible method to estimate dietary adequacy in a multi-site preconception maternal nutrition RCT. Food Nutr Res. 2017 Apr 11:61(1):1311185.

22. Srivastava T, Negandhi H, Neogi SB, Sharma J, Saxena R. Methods for hemoglobin estimation: a review of "what works". J Hematol Transfus. 2014; 2(3):1028.

23. Wasnik M, Tirpude R, Wasnik N, Agrawal VP. Validation of different tests for haemoglobin estimation. IJBR. 2014;05(01):29-30.

24. Ghosh JS, Singh A, Bhattacharya A, Ray S, Yunus S, Zodpey SP. Dimensions of nutritional vulnerability: assessment of women and children in Sahariya tribal community of Madhya Pradesh in India. Indian J Public Health. 2013; 57:260-7.

25. Panigrahi A, Sahoo PB. Nutritional anaemia and its correlates among women of reproductive age in an urban slum of Bhubaneshwar. Orissa Indian J Public Health Oct-Dec. 2011;55(4):317-20.

26. National Family Health Survey-4; 2015-16. District Fact Sheet Belgaum, Karnataka. Ministry of Health and Family Welfare, Government of India. Available at http://rchiips.org/NFHS/FCTS/KA/KA_FactSheet_555_ Belgaum.pdf

27. National Family Health Survey-4; 2015-16. State Fact Sheet Karnataka. Ministry of Health and Family Welfare, Government of India. Available at http://rchiips.org/NFHS/pdf/NFHS4/KA_FactSheet.pdf.

28. P. Ramesh; Malnutrition among women in Kerala: an analysis of trends, differentials and determinants, Gokhale Institute of Politics and Economics (Deemed University) Pune - 411004 Maharashtra, India, 2011.

29. Islam MZ, Karkkainen M, Christel LA. Dietary calcium intake in young Bangladeshi female garment factory workers, Dhaka. Asian J ClinNutr. 2013; 5(1):8-17.

30. Sulakshana SB, Naik VA, Mallapur MD. Nutritional status of adolescent girls residing in rural area: a community based cross sectional study. J Sci Soc. 2014:41(1):210-2.

31. Choudhary S. Mishra, Shukla. Dietary pattern and nutrition related knowledge of rural adolescent girls. Indian J. Prev. Med. 2010;41(4):207-15.

32. Schaefer SE, Erber E, Trzaskos JP, Roache C, Osborne G, Sharma S. Sources of food affect dietary adequacy of Inuit women of childbearing age in Arctic Canada health population. J Health Popul Nutr. 2011 Oct:29(5):454-64.

33. Majid SA, Fatourechi, Lesanpezeshki M, Ahmadnezhad E. Prevalence of Anemia and Correlated Factors in the Reproductive Age Women in Rural Areas of Tabas, Iran. J Family Reprod Health 2013 Sep;7(3):139-144.

34. Ene-Obong HN, Enugu Gl, Uwaegbute AC. Determinants of health and nutritional status of rural Nigerian women. J Health Popul Nutr. 2001 Dec; 19(4):320-30.

35. Ali M, Rehman H, Husain MS. Status of food insecurity at household level in rural India: a case study of Uttar Pradesh. International Journal of Physical and Social Sciences. 2012 August;2(8):227-44.

36. Chaparro C. Household food insecurity and nutritional status of women of reproductive age and children under 5 years of age in five departments of the western highlands of Guatemala: an analysis of data from the National Maternal-Infant Health Survey 2008-09 of Guatemala. Washington (DC): FHI 360/FANTA; 2012

37. Rapid Assessment Survey of Developmental Programmes 2015-2016. Government of Karnataka. Available at http://des.kar.nic.in/docs/rapidsurvey-english-final-2015-16.pdf.

38. March of Dimes, PMNCH, Save the Children, WHO. Born Too Soon: The Global Action Report on Preterm Birth. Geneva: World Health Organization; 2012 